\title{
Effect of staurosporine and ucn-01 on gemcitabine cytotoxicity in relation to cell cycle effects and p53 status
}

\author{
J Sigmond ${ }^{1}$, LG Leon' ${ }^{1}$ JAE Kamphuis ${ }^{1}$, AM Bergman ${ }^{1 /}$ and GJ Peters ${ }^{1 *}$ \\ Correspondence: gj.peters@vumc.nl \\ 'Department of Medical Oncology, VU University Medical Center, Amsterdam, the Netherlands. \\ \#Present address: Netherlands Cancer Institute, Amsterdam, the Netherlands.
}

\begin{abstract}
Gemcitabine $(\mathrm{dFdC})$ is an anti-cancer agent that is affected by cell cycle modulation. Staurosporine and 7-hydroxystaurosporine (UCN-01) are potent protein kinase C (PKC) inhibitors as well as inhibitors of cyclin dependent kinase 2 (cdk2) and were therefore investigated for potential synergism, cell cycle modulation, cell death induction, and the role of the p53 protein. Lovo colon cancer cell line variants with wild type and mutant p53 (Lovo 175x2) or inactive (Lovo Li) were used for this purpose.

Combinations of $\mathrm{dFdC}$ with staurosporine were most synergistic when cells were exposed to $\mathrm{dFdC}$ prior to staurosporine, while for UCN-01 the simultaneous exposure was most synergistic. This synergism appeared to be related with abrogation of the cell cycle and cell cycle proteins. For $\mathrm{dFdC}(1.0 \mu \mathrm{M})$, a gradual time dependent increase of cells in $\mathrm{S}$ phase (up to $40 \%)$ was observed in all Lovo variants. Staurosporine $(0.05 \mu \mathrm{M})$ initially induced accumulation of cells in the $\mathrm{G}_{2} / \mathrm{M}_{\mathrm{phase}}$ (after $24 \mathrm{hr}$ ), while $48 \mathrm{hr}$ exposure showed accumulation in the S-phase. UCN-01 $(0.5 \mu \mathrm{M})$ caused an arrest in $\mathrm{G}_{0} / \mathrm{G}_{1}$ after $24 \mathrm{hr}$ exposure, while after $48 \mathrm{hr}$ cells accumulated in the $\mathrm{S}$ phase. Simultaneous exposure to $\mathrm{dFdC}$ combinations showed an average cell cycle distribution of both drugs when used alone. In sequential addition of $\mathrm{dFdC}$ combinations, the first drug dominated the cell cycle distribution.

Synergism of gemcitabine combinations was associated with induction of cell death by UCN-01, which was 2-fold higher in Lovo 175x2 (mutant p53) compared to other Lovo variants. Additive effects in induction of cell death were observed at the simultaneous addition of $\mathrm{dFdC}$ and $\mathrm{UCN}-01$, but exposure to $\mathrm{dFdC}$ prior to UCN-01 caused a 2-fold higher induction of cell death than the sum of each compound alone in Lovo $175 \mathrm{x} 2$ cells, in contrast to the other lines. Accumulation of cells in the G2/M phase prevented repair of DNA damage, resulting in increased apoptosis. These data demonstrate that staurosporine and $\mathrm{UCN}-01$ affect $\mathrm{dFdC}$ cytotoxicity via modulation of the cell cycle.
\end{abstract}

Keywords: gemcitabine, staurosporin, UCN-01, protein kinase C, p53, E2F, cell cycle, cell death

\section{Introduction}

Gemcitabine $(\mathrm{dFdC})$ is widely used for treatment of solid tumors and almost always combined, either with cytototic drugs such as cisplatin, paclitaxel and 5-fluorouracil (5-FU) or targeted drugs such as erlotinib [1]. dFdC is a deoxynucleoside analogue, in which the 2 ' hydrogens of the nucleoside deoxycytidine are replaced by fluoride. $\mathrm{dFdC}$ needs to be phosphorylated by deoxycytidine kinase (dCK) to become active. The main mechanism of action is incorporation of its active metabolite $\mathrm{dFdC}$ triphosphate (dFdCTP) into the DNA [2]. Furthermore, dFdC diphosphate (dFdCDP) inhibits ribonucleotide reductase (RNR), an essential enzyme that is involved in DNA synthesis [3]. RNR is responsible for the reduction of ribonucleotides to their corresponding deoxyribonucleotides that will be further phosphorylated to deoxynucleoside triphosphates
(dNTPs). Inhibition of RNR is one of the self-potentiating properties of $\mathrm{dFdC}$ since this will lead to depletion of dNTP pools, increasing the $\mathrm{dFdC}$ incorporation into the DNA [4]. Combination therapies are rationally designed in order to increase the efficacy of the separate drugs and circumvent development of resistance. E.g. the combination of cisplatin and gemcitabine is based on a decreased repair of DNA-platinum adducts as well as an increased dFdC incorporation into DNA. Following preclinical data on the synergism of $\mathrm{dFdC}$ with cisplatin $[5,6]$, this combination is now considered to be one of the most active schedules against NSCLC and bladder cancer $[1,7]$.

Hence, increasing the efficacy of a combination will benefit most from the use of agents that work at different targets, inducing additive effects or ideally synergistic interactions. DNA damaging agents such as $\mathrm{dFdC}$ that

(C) 2012 Peters et al; licensee Herbert Publications Ltd. This is an open access article distributed under the terms of Creative Commons Attribution License (http://creativecommons.org/licenses/by/3.0),This permits unrestricted use, distribution, and reproduction in any medium, provided the original work is properly cited. 
arrest cells in the $S$ phase are suitable agents to be combined with cell cycle inhibitors that act on different cell cycle phases thereby increasing the therapeutic response. The protein kinase $C$ (PKC) inhibitors staurosporine and its analogue UCN-01 are agents that induce cell cycle arrest in preclinical experimentsts. Staurosporine is an indolo (2,3a) carbazole derived from bacterium Streptomyces which turned out to be a potent but non-selective inhibitor of PKC Staurosporine induces G1 [8] and G2 arrest [9] depending on the concentration $[10,11]$. Staurosporine is a potent inducer of cell death. [9,12]. Since staurosporine inhibits signal transduction pathways that regulate growth factor response, proliferation and apoptosis, and some preclinical results showed promising antitumor effects, new analogues were developed with higher selectivity for PKC, such as 7-hydroxystaurosporine (UCN-01). UCN-01 exhibited a potent anti-tumor activity in both in vitro and in vivo tumor models [13]. Besides PKC inhibition, staurosporine and UCN-01 can affect kinases that are related to PKCs such as cyclin dependent kinases (cdks), which are involved in cell cycle progression. E.g. Kawakami demonstrated an inhibitory effect on cdks 2, 4 and 6 in NSCLC cell line A549 [14]. This decline increased levels of cdk inhibitors p27 and p21 members of the Cip/Kip family. Together with a decrease in cycline D3 levels with concomitant reduced phosphorylation of the retinoblastoma $(\mathrm{Rb})$ gene all contribute to the induced G1 phase arrest by UCN-01 $[15,16,17]$. UCN-01 also induces cell death in cell lines that lack p53 function while the induced cytotoxicity is p53 independent $[18,19]$.

In this study, we evaluated the combination of $\mathrm{dFdC}$ with staurosporine and UCN-01 focusing on growth inhibition, cell death induction, cell cycle and the role of the p53 protein. Lovo colon cancer cell line variants with wild type (Lovo B2), non-functional (Lovo Li) and mutant (Lovo 175×2) p53 were used for this purpose.

\section{Materials and methods \\ Drugs and biochemicals}

Dulbecco's Modified Eagle's Medium (DMEM) was obtained from Flow Laboratories (Irvine, Scotland). Both fetal calf serum (FCS) and Hank's balanced salt solution (HBSS) were purchased from Gibco Europe (Paisly, UK). Gemcitabine (Gemzar, dFdC) was provided by Eli Lilly Research Laboratories, (Indianapolis, IN, USA), UCN-01 was kindly provided by dr. Bob Schultz at the $\mathrm{NCl}$ (Bethesda, MD USA). Staurosporine and propidium iodide were from Sigma Chemical Co (St Louis, MO, UK). Hybond Enhanced ChemoLuminescence (ECL) nitrocellulose membranes, Hyperfilm ECL plus and ECL detection kit were obtained from Amersham International (Buckinghamshire, UK). Mouse monoclonal antibodies against human P53 (Clone Ab-2) and against E2F1 (clone $\mathrm{KH}-95$ ) were from EMD Biosciences, Darmstadt, Germany, and from Santa Cruz Biotechnologies, respectively. The secondary antibody goat-anti-mouse was from DAKO (Glostrup, Denmark). Unless otherwise specified, all other chemicals were of analytical grade and commercially available.

\section{Cell lines}

Lovo is a solid human colon cancer cell line. Lovo colon cancer cell line variants with wild type (Lovo B2), nonfunctional (Lovo Li) and mutant (Lovo 175×2) p53 with a mutation at position 175 (Arg-His) leading to gain of function [20] were grown as monolayers and were cultured in DMEM medium, containing 10\% FCS and 20 mM HEPES at $37^{\circ} \mathrm{C}$ under an atmosphere of $5 \% \mathrm{CO}_{2}$.

\section{Growth inhibition studies}

Growth inhibitory effects of dFdC, Staurosporine and UCN-01 were evaluated with the sulforhodamine-B (SRB assay) as described earlier [21]. Shortly, cells of Lovo variants (5000 cells/well) were exposed to various drug concentrations for $72 \mathrm{hrs}$. Thereafter, cellular protein was precipitated, fixed and stained with SRB and the optical density was measured at $540 \mathrm{~nm}$. The interactions were studied at a fixed ratio based on the $\mathrm{IC}_{50}$ concentrations of the drugs using the multiple drug effect analysis software program developed by Chou and Talalay [22], (Calcusyn software, BioSoft, Ferguson, MO, 1996) which enables to determine drug interactions, given by the Combination Index (Cl), in which a $\mathrm{Cl}>1.1$ represents antagonism, $0.9<\mathrm{Cl}<1.1$ additivity and $\mathrm{Cl}<0.9$ synergism. $\mathrm{Cl}$ values are plotted against fraction affected (FA) resulting in CI-FA plots; a FA of 0 is normal $100 \%$ growth, $\mathrm{FA}=0.5$ represents the IC50 value and a FA of 1 represents $100 \%$ growth inhibition. In the $\mathrm{Cl}-\mathrm{FA}$ plot the $\mathrm{Cl}$ values at $\mathrm{FA}>0.5$ are evaluated and per experiment only the $\mathrm{Cl}$ values at FA $0.5,0.75$ and 0.9 were averaged. Different treatment schedules were used; simultaneous exposure and sequential exposure with $\mathrm{dFdC}$ as the first drug and PKC inhibitors as the second drug added $24 \mathrm{hr}$ after the first drug without refreshing the medium.

\section{FACS analysis}

Cell cycle distribution and induction of apoptosis was analysed by FACScan (Becton Dickinson, Mount View, CA) using Propidium lodide (PI) as DNA binding agent. After drug treatment, adherent and floating cells were harvested and counted. After centrifugation (1200 rpm, $5 \mathrm{~min}$ ), the pellet was gently resuspended in $1 \mathrm{ml}$ hypotonic propidium iodide (P1)-solution $(50 \mu \mathrm{g} / \mathrm{ml} \mathrm{PI}, 0.1 \%$ sodium citrate, Triton $X-100,0.1 \mathrm{mg} / \mathrm{ml}$ ribonuclease $A$ ) to a concentration of $5 \times 10^{5}-10^{6} \mathrm{cell} / \mathrm{s} / \mathrm{ml}$ in round-bottomed fluorescent activated cell sorting (FACS) tubes. Cells were analysed by using Cellquest software (Becton Dickinson, Mount View, CA).

\section{Western blot analysis}

Frozen cell pellets were lysed in buffer containing $0.1 \%$ Triton X-100, $150 \mathrm{mM} \mathrm{NaCl}, 10 \mathrm{mM}$ Tris $\mathrm{HCl} \mathrm{pH} \mathrm{7.6,} \mathrm{and}$ $5 \mathrm{mM}$ EDTA. Protein content was measured using the 
BioRad assay. For determination of protein expression, $25 \mu \mathrm{g}$ protein was loaded and separated on a $10 \%$ SDSPAGE gel (acrylamide:bis 29:1), followed by blotting on a nitrocellulose membrane. Blocking occurred overnight at $4^{\circ} \mathrm{C}$ with $5 \%$ milk powder (Protifar) in TBS-T (TBS (20 $\mathrm{mM}$ Tris $\mathrm{pH} 7.6$ and $150 \mathrm{mM} \mathrm{NaCl}) \mathrm{mM}+0.05 \%$ Tween-20). Membranes were incubated for one hr with the primary antibodies (dilution 1:100). Subsequently the membranes were incubated with HRP conjugated anti mouse or antirabbit antibodies (dilution 1:1000). After each incubation step the nitrocellulose membranes were washed several times with TBS-T. The HRP was visualized by means of $\mathrm{ECL}(+)$ detection solution and autoradiography and quantified by scanning on a GS-690 Bio-rad scanner (Bio-Rad, Hercules, California, USA). Levels of expression were reported relative to the untreated control samples [23].

\section{Results}

\section{Growth inhibition studies}

In order to study the role of p53 mutations on sensitivity to and modulation by staurosporine and UCN-01 we used three Lovo colon cancer variants (Lovo B2, empty vector plasmid control; wild-type p53), Lovo Li (functionally inactive p53) and Lovo $175 \times 2$ (transfected with mutated p53). Lovo $175 \times 2$ was less sensitive to all three drugs although this difference was minor for staurosporine (Table 1).

The combination indices of $\mathrm{dFdC}$ with staurosporine or UCN-01 are summarized in Table 2. The simultaneous combination of $\mathrm{dFdC}$ with $\mathrm{UCN}-01$ was synergistic in all Lovo variants. Furthermore, the highest synergistic effect of the combination with UCN-01 was found in mut p53 Lovo $175 \times 2$ compared to the other Lovo variants (Figure 1). Also for the combination of $\mathrm{dFdC}$ with staurosporine strong synergism was observed in Lovo $175 \times 2$ but not in Lovo Li cells, while in Lovo B2, the combination was not additive. Because exposure to $\mathrm{dFdC}$ prior to staurosporin or $\mathrm{UCN}-01$ induced more cell death than vice versa, we also studied this sequence, by adding staurosporin and UCN-01 $24 \mathrm{hr}$ after dFdC. The combination with UCN-01 was also synergistic in Lovo Li and Lovo 175x2 at sequential exposure although to a lesser extent than the simultaneous combination. However, in Lovo B2 cells the sequential combination with UCN-01 even changed to additive and that with staurosporin to synergism, while the effects in Lovo Li and Lovo175x2 hardly changed.

\section{Cell cycle analysis}

Representative data on cell cycle distribution of combinations of dFdC and staurosporin or UCN-01 are shown in Figure 2. No clear differences were observed between the Lovo variants regarding the effect of the drugs on cell cycle distribution. For $\mathrm{dFdC}(1.0 \mu \mathrm{M})$, a gradual increase (about 2-fold) of cells in $\mathrm{S}$ phase was observed in all Lovo variants. Exposure to staurosporine $(0.05 \mu \mathrm{M})$ initially induced accumulation (from 35 to about $60 \%$ ) of cells in the $\mathrm{G}_{2} / \mathrm{M}$ phase (after $24 \mathrm{hr}$ ), which shifted after $48 \mathrm{hr}$ exposure to the $\mathrm{S}$-phase. An arrest in $\mathrm{G}_{0} / \mathrm{G}_{1}$ was observed after $24 \mathrm{hr}$ exposure UCN-01 $(0.5 \mu \mathrm{M})$, while

Table 1. Sensitivity of Lovo variants to gemcitabine, staurosporine and UCN-01.

Values are means \pm SE of at least 3 separate experiments.

\begin{tabular}{llll}
\hline $\mathrm{IC}_{50}(\mathrm{nM})$ & Lovo B2 & Lovo Li & Lovo 175x2 \\
\hline Gemcitabine & $4 \pm 1$ & $0.8 \pm 0.2$ & $22 \pm 4.8$ \\
Staurosporine & $3 \pm 0.6$ & $2 \pm 0.6$ & $5 \pm 0.9$ \\
UCN-01 & $20 \pm 2$ & $15 \pm 2.3$ & $91 \pm 14$ \\
\hline
\end{tabular}

Sensitivity to the drugs was determined using the SRB assay with 72-hr exposure.

Table 2. Combination indices for combinations of simultaneous (sim) and sequential (seq) exposure of gemcitabine (dFdC) followed by UCN-01 or staurosporine (STS) in Lovo variants

\begin{tabular}{lllllllll}
\hline & \multicolumn{7}{c}{ Combination Index \pm SEM } \\
\hline LFdC / UCN (1:1) & sim & $0.39 \pm 0.08$ & +++ & $0.47 \pm 0.11$ & +++ & $0.17 \pm 0.04$ & ++++ \\
dFdC -> UCN-01 & seq & $0.91 \pm 0.28$ & \pm & $0.57 \pm 0.05$ & +++ & $0.45 \pm 0.15$ & +++ \\
dFdC/STS (1:1) & sim & $1.17 \pm 0.34$ & - & $1.06 \pm 0.20$ & \pm & $0.44 \pm 0.02$ & +++ \\
dFdC -> STS & seq & $0.32+0.10$ & +++ & $0.87 \pm 0.28$ & + & $0.53 \pm 0.26$ & +++ \\
\hline
\end{tabular}

Evaluation of possible synergism using the median drug effect analysis method of Chou and Talalay (Biosoft). CI is given as the mean of CI values which represent the synergistic effect calculated for growth inhibition of 50, 75 and 90\%. Symbols: ++++ strong synergism, +++ synergism, + slight synergism, + nearly additive, - slight antagonism. Results are means + SEM of at least 3 separate experiments. 


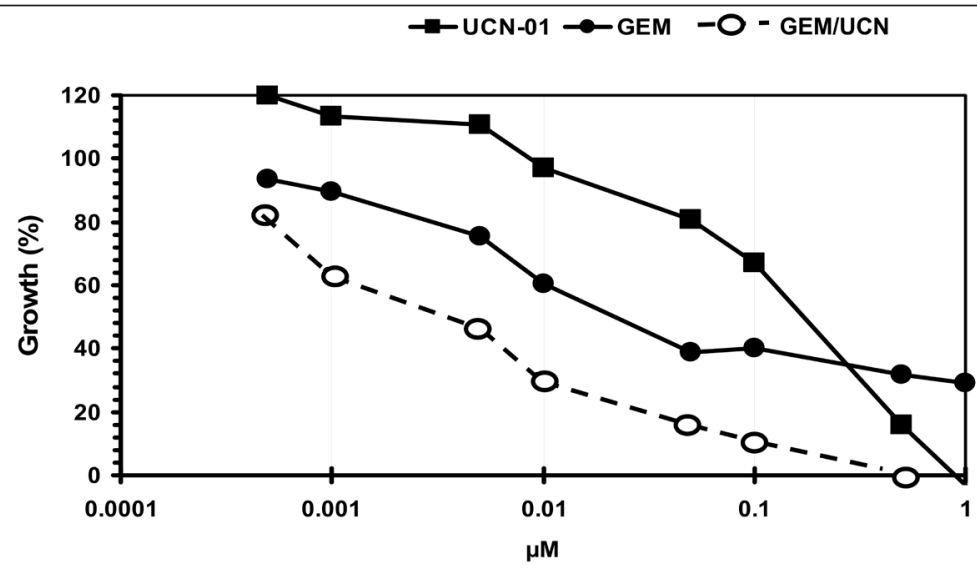

Figure 1. Representative growth inhibition curves of the simultaneous combination of gemcitabine (GEM) with UCN-01 in a fixed molar ratio in LovoB2 cells.

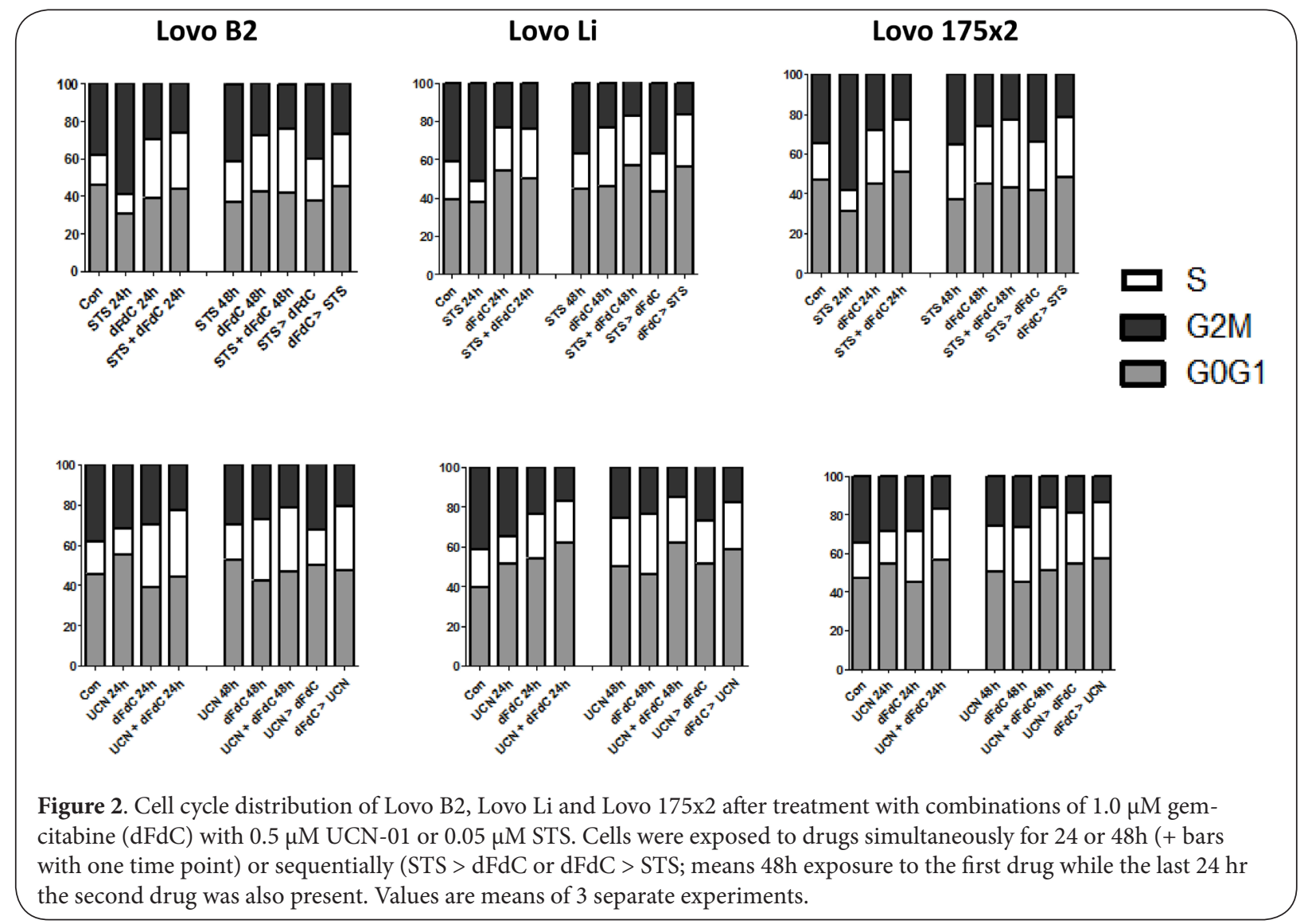

after $48 \mathrm{hr}$ cells accumulated in the $S$ phase (up to almost 2 -fold). Simultaneous exposure to $\mathrm{dFdC}$ combinations showed an average cell cycle distribution of each drug alone. In sequentially given drug combinations, the cell cycle distribution of the first drug added was dominant.

Induction of cell death

Induction of cell death was determined by analysis of the sub- $G_{1}$ fraction of the FACS data. Cell death induction was investigated after treatment for $72 \mathrm{hr}$ with $\mathrm{dFdC}$ combinations (Table 3). In Lovo B2 and Lovo Li cells dFdC induced more cell death than in Lovo $175 \times 2$. However, in Lovo $175 \times 2$ cells with mutant p53 UCN-01 and staurosporine induced more cell death compared to the other Lovo variants. The combination of $\mathrm{dFdC}$ with UCN-01 produced more cell death in Lovo 175×2 compared to Lovo Li and Lovo B2. 
Sigmond et al. Journal of Cancer Therapeutics \& Research 2012, http://www.hoajonline.com/journals/pdf/2049-7962-1-29.pdf

Table 3. Induction of cell death after treatment of Lovo Li, Lovo B2 and Lovo $175 \times 2$ with drug combinations of gemcitabine $(\mathrm{dFdC})(1.0 \mu \mathrm{M})$ with $\mathrm{UCN}-01(0.5 \mu \mathrm{M})$ or staurosporine (STS) $(0.05 \mu \mathrm{M})$.

\begin{tabular}{|c|c|c|c|c|}
\hline & & Lovo B2 & Lovo Li & $\begin{array}{l}\text { Lovo } \\
175 \times 2\end{array}$ \\
\hline \multirow{6}{*}{$24 \mathrm{~h}$} & Control & $1.7 \pm 1.0$ & $3.1 \pm 1.5$ & $1.8 \pm 0.9$ \\
\hline & $\mathrm{dFdC}$ & $2.1 \pm 0.5$ & $4.8 \pm 1.9$ & $5.9 \pm 2.1$ \\
\hline & STS & $4.9 \pm 1.1$ & $5.3 \pm 2.0$ & $11.2 \pm 1.7$ \\
\hline & UCN & $5.5 \pm 1.2$ & $4.7 \pm 1.9$ & $12.2 \pm 1.8$ \\
\hline & $\mathrm{STS}+\mathrm{dFdC}$ & $6.0 \pm 2.0$ & $9.9 \pm 3.3$ & $17.3 \pm 2.5$ \\
\hline & $\mathrm{UCN}+\mathrm{dFdC}$ & $7.5 \pm 2.1$ & $7.4 \pm 2.5$ & $22.2 \pm 2.3$ \\
\hline \multirow[t]{9}{*}{$48 \mathrm{~h}$} & $\mathrm{dFdC}$ & $7.3 \pm 2.2$ & $8.4 \pm 2.1$ & $4.8 \pm 1.1$ \\
\hline & STS & $12.2 \pm 3.5$ & $6.0 \pm 1.5$ & $15.0 \pm 3.0$ \\
\hline & UCN & $11.3 \pm 2.5$ & $12.7 \pm 1.8$ & $20.1 \pm 2.5$ \\
\hline & $\mathrm{STS}+\mathrm{dFdC}$ & $12.2 \pm 1.9$ & $15.2 \pm 3.0$ & $16.3 \pm 1.2$ \\
\hline & $\mathrm{UCN}+\mathrm{dFdC}$ & $12.7 \pm 1.8$ & $18.7 \pm 2.5$ & $29.2 \pm 2.3$ \\
\hline & STS $>$ dFdC & $13.1 \pm 3.0$ & $11.3 \pm 1.8$ & $15.6 \pm 2.0$ \\
\hline & $\mathrm{UCN}>\mathrm{dFdC}$ & $10.5 \pm 2.2$ & $12.0 \pm 1.7$ & $26.1 \pm 2.2$ \\
\hline & $\mathrm{dFdC}>\mathrm{STS}$ & $16.5 \pm 2.7$ & $17.2 \pm 2.8$ & $19.5 \pm 2.1$ \\
\hline & $\mathrm{dFdC}>\mathrm{UCN}$ & $16.4 \pm 3.0$ & $20.4 \pm 2.5$ & $33.1 \pm 3.1$ \\
\hline
\end{tabular}

Cells were exposed to drugs simultaneously for 24 or $48 \mathrm{~h}$, indicated by + (drug + drug) or sequentially indicated by $>$, this means $48 \mathrm{~h}$ exposure to the first drug and the last $24 \mathrm{~h}$ also to the second drug. Values are means + SEM of 3 separate experiments and the values are expressed in percentage of cell in SubG1 phase (\%).

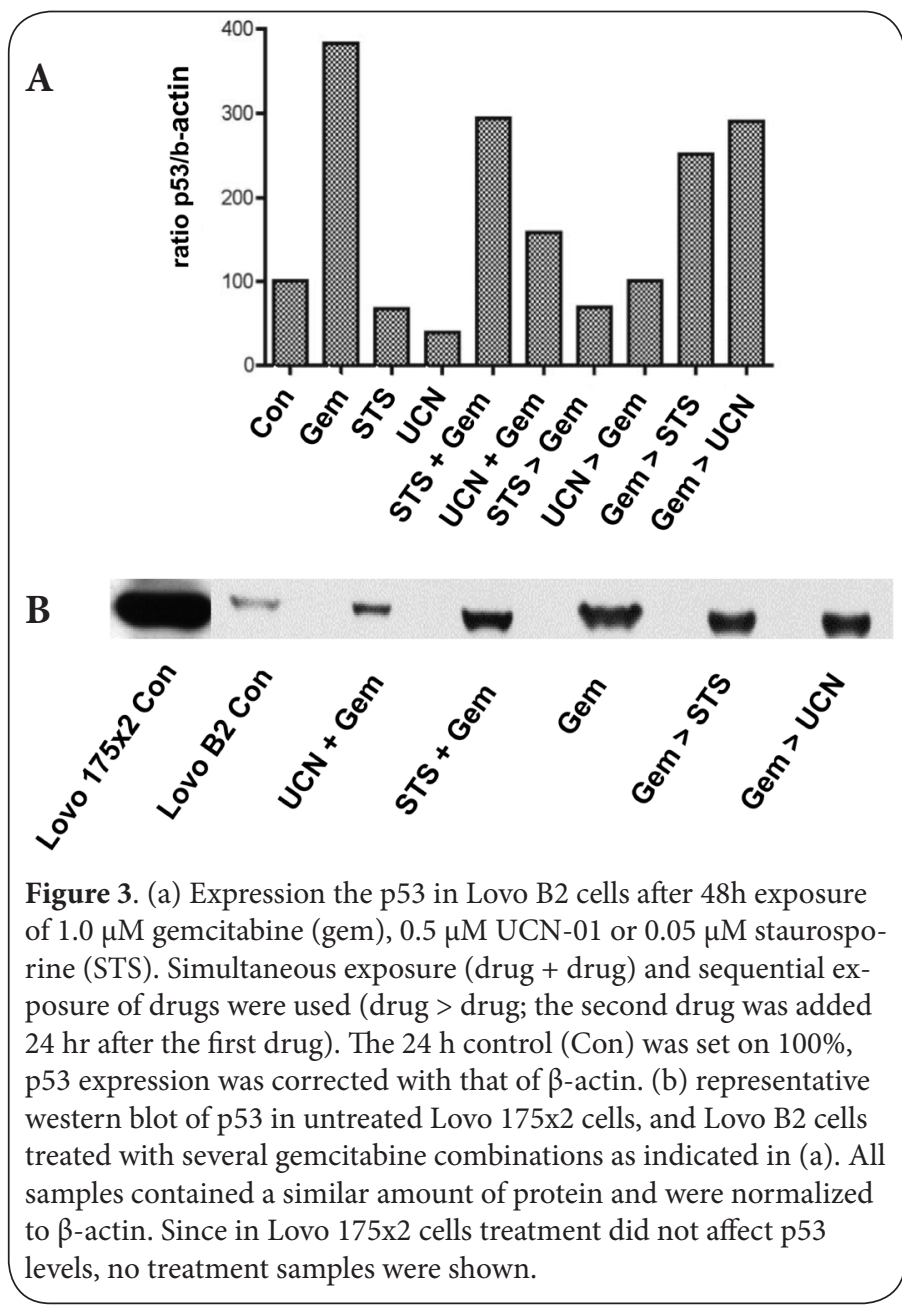

This is related with the increased induction of cell death by UCN-01 in Lovo 175×2 compared with the other Lovo variants. A more than additive cell kill of $48 \mathrm{hr}$ exposure by $\mathrm{dFdC}$ followed by staurosporine or UCN-01 was observed in all cell lines. However, the most striking synergistic effect was observed in Lovo $175 \times 2$. Induction of cell death was 2 -fold higher compared to the additional effect of used drugs alone. Furthermore, a more than additive cell kill was also observed after treatment of Lovo $175 \times 2$ cells with simultaneous addition of $\mathrm{dFdC}$ and UCN-01.

\section{p53 and E2F protein expression}

Since for UCN-01 it has been reported that it may bypass P53 dependent cell death we investigated its expression in the three lines upon drug exposure. As expected in Lovo Li P53 was not induced, while in Lovo $175 \times 2$ the high expression was not affected (data not shown) . However, in Lovo B2 single drug exposure to $\mathrm{dFdC}$ upregulated p53 about 4-fold at $48 \mathrm{hr}$, but after exposure to STS or UCN-01 a slight decrease was found (Figure 3). In simultaneous drug exposure, drugs contributed equally to p53 expression leading to about 2 -fold upregulation. In sequential drug exposure, the first drug given dominated in the p53 induction, leading to no change in p53 expression when UCN-01 or STS were added first, although a high extent of cell death was found in this sequence. Since also in the Lovo $175 \times 2$ cells a similar and higher extent of cell death was found than in the wt p53, induction of cell death follows a p53 independent pathway.

E2F expression showed a differential expression in the combinations. In Lovo $175 \times 2$ it was only induced in the sequential combinations of UCN-01 (Figure 4). For dFdC we found a small decrease and for STS a small increase. In the STS combinations E2F was decreased when dFdC preceded STS. In the Lovo B2 cells UCN-01 and STS increased E2F expression. But in the sequential combinations it was decreased when $\mathrm{dFdC}$ preceded STS or UCN-01.

\section{Discussion}

Combinations of dFdC with UCN-01 or staurosporine are most effective when cells were exposed to dFdC prior to staurosporine or UCN-01. Apparently the cell cycle 


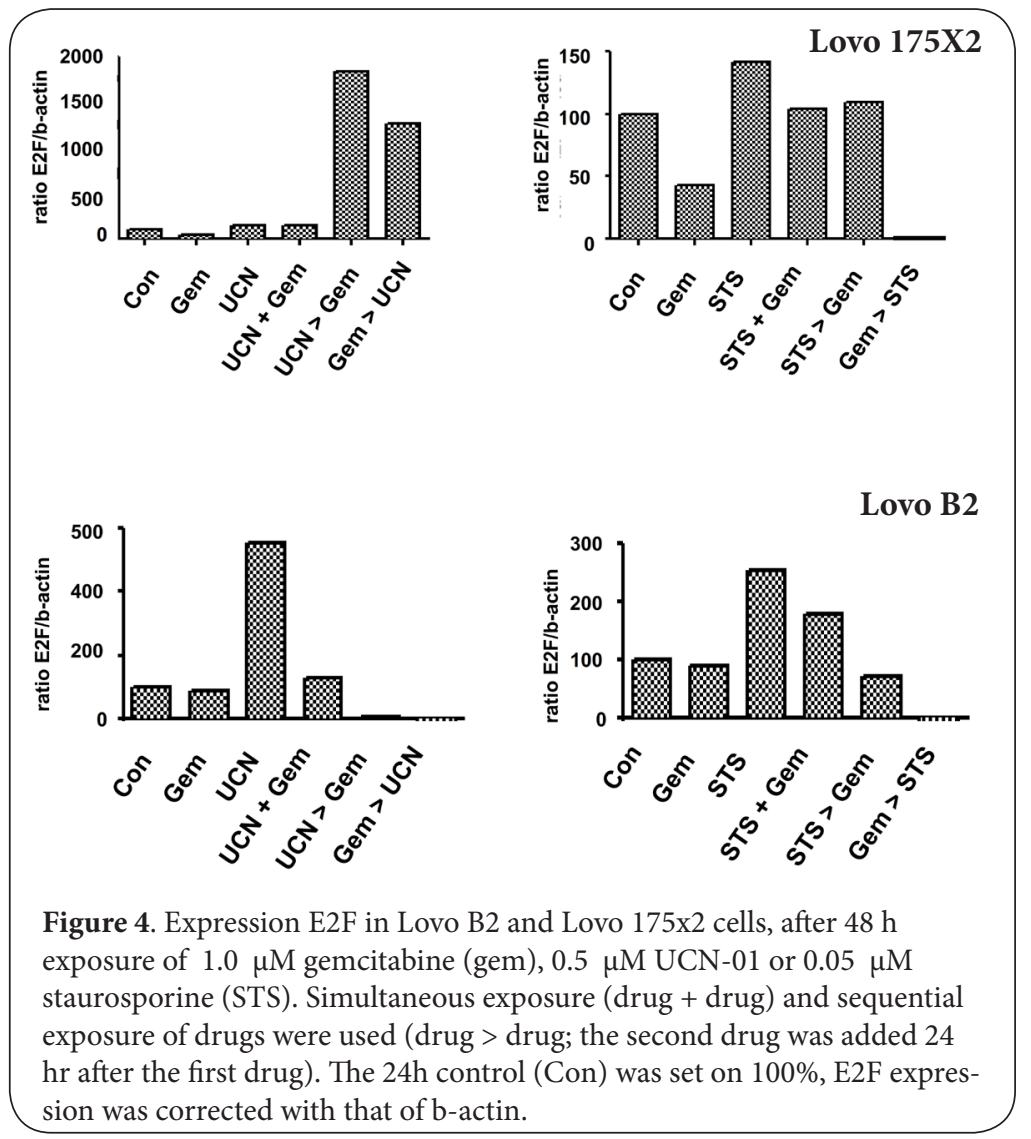

effects as induced by the first drug, prevented cells to cycle further and cells were forced into apoptosis which was most pronounced for the $\mathrm{dFdC}$ and UCN-01 combination in the cells with mutant p53, in contrast to the other lines. Staurosporine and UCN-01 have been developed as protein kinase Ca inhibitors, but have multiple other cell cycle targeted effects. We demonstrated earlier in non-small cell lung cancer cells that potentiation by staurosporine is independent of PKC inhibition, but associated with a decrease of the cell cycle regulator E2F and an even more pronounced decrease of the gemcitabine target ribonucleotide reductase [23]. UCN-01 is even less specific for PKC and is a known abrogator of cell cycle proteins, such as cdk 2 and 4, the G2/M and S checkpoint via "checkpoint kinase (chk)" chk1 and possibly chk2. [24]. Hence low concentrations of UCN-01 cause $S$ phase arrest progressing into the $\mathrm{G} 2$ phase before going into apoptosis, while high concentrations cause immediate $\mathrm{S}->\mathrm{M}$ transition [25].

Abrogation of the $\mathrm{G} 2 / \mathrm{M}$ checkpoint is an attractive target when it is combined with DNA damaging drugs. DNA damage triggers the protein kinases ataxia telangiectasia (ATM) and ATM-Rad3-related (ATR) to activate chk1 and chk2, inactivating the phosphatase $\mathrm{cdc} 25 \mathrm{c}$ by phosphorylation, which will prevent cyclineB-cdk1 to be dephosphorylated, arresting cells in G2-M transition of cells to repair the induced DNA damage. In cells with wild-type p53, DNA damage will stimulate p53, leading to an S-phase arrest and allowing cells to repair DNA damage. In mut-p53 cells this regulation is abrogated, so that UCN-01 by inhibition of the G2/M checkpoint regulators, will increase DNA damage. Moreover UCN-01 will further prevent DNA repair and enhance the effect of deoxynucleoside analogues ara-C, dFdC, 5-FU [26-31], the purine analogue fludarabine $[26,32]$ and DNA binding agents such as cisplatin, thiotepa, mitomycin $C$, cisplatin, melphalan and topotecan [26]. Treatment with a DNA damaging drug (cisplatin, 5FU, nucleoside analogs or radiation) prior to UCN-01 or a novel ChK1 inhibitor (SCH00766) was synergistic and induced more cell death than vice versa through abrogation of the $\mathrm{G} 2 / \mathrm{M}$ checkpoint and was associated by reduced expression of cyclins $A$ and $B$ and activation of Cdk1 [33,34].

$\mathrm{UCN}-01$ and $\mathrm{dFdC}$ combinations induced more cell death in $\mathrm{p} 53$ mutant Lovo $175 \times 2$ cells than wt $\mathrm{p} 53$ cells. In addition to dFdC this holds for NSCLC cells treated with cisplatin or the topoisomerase I inhibitor SN38. In wt p53 Lovo B2 the induction was additive since UCN-01 led to a G1 arrest and in the combination to a decrease in E2F and not to the abrogation of the G2/M checkpoint. The 
observation that in cancer cells with inactive p53, post treatment with a checkpoint inhibitor such as UCN-01 enhanced sensitivity to DNA damaging agents is an excellent approach for combination therapy. Indeed most cancer cells have mutations in the $\mathrm{G} 1 / \mathrm{S}$ checkpoint (such as the tumor suppressor genes p53 and $\mathrm{Rb}$ ) and only exceptionally cancer cells have defects in the G2/M checkpoint.

Kroep et al showed that the activity of dCK is correlated with dFdC sensitivity of xenograft mouse models [35]. In NSCLC cells treatment with staurosporin increased dCK activity, possibly by a mixture of a direct effect [23] or via posttranslational regulation, such as protein phosphorylation. Indeed, activation of dCK may involve a phosphorylationdependent step, since okadaic acid and calyculin A, broadspectrum inhibitors of serine/threonine-specific protein phosphatases, significantly increased dCK activities [36,37]. In contrast, $\lambda$ protein phosphatase digestion abolished the dCK activity of cell extracts [38]. In addition, Smal et al., demonstrated that recombinant; His-tagged dCK can be phosphorylated [39]. The synergistic effect of dFdC with staurosporin or UCN-01 in colon cancer cells may partly be similar to that in NSCLC and due to downregulation of free $E 2 F$, an upregulation of $d C K$ and a downregulation of ribonucleotide reductase. Since UCN-01 clearly interferes with cdks, the action of both UCN-01 and staurosporine in combination with $\mathrm{dFdC}$ seems also to be related to cell cycle effects by preventing cells to progress in cell cycle after $\mathrm{dFdC}$ exposure leading to more cell death.

In conclusion, combinations of $\mathrm{dFdC}$ with $\mathrm{UCN}-01$ or staurosporine were most effective when cells were exposed to $\mathrm{dFdC}$ prior to staurosporine or UCN-01. Targeting different cell cycle phases and abrogation of cell cycle checkpoints are both attractive strategies in combination with DNA damaging agents since the sequential combination of DNA damaging agents prior to checkpoint abrogators such as UCN-01 and novel analogs, prevent repair of DNA damage leading to cell death.

\section{Competing interests}

The authors declare that they have no competing interests.

Authors' contribution

The main part of the paper has been designed and written by J Sigmond and GJ Peters. J Kamphuis and L Leon contributed to part of the paper and wrote some parts, while A Bergman took part in the supervision and writing as well. Authors' acknowledgements

The research was support by an educational grant

from Eli Lilly \& Co, Indianapolis, IN, USA.

Publication history

Received: 29-Aug-2012 Revised: 29-Sep-2012

Accepted: 15-Oct-2012 Published: 29-Oct-2012

\section{References}

1. Toschi L, Finocchiaro G, Bartolini S, Gioia V, Cappuzzo F: Role of gemcitabine in cancer therapy. Future Oncol 2005, 1:7-17. | Article | PubMed
2. Bergman AM, Pinedo HM, Peters GJ: Determinants of resistance to 2',2'-difluorodeoxycytidine (gemcitabine). Drug Resist Updat 2002, 5:19-33. I Article I PubMed

3. Heinemann V, Xu YZ, Chubb S, Sen A, Hertel LW, Grindey GB, Plunkett $\mathrm{W}$ : Inhibition of ribonucleotide reduction in CCRF-CEM cells by 2',2'-difluorodeoxycytidine. Mol Pharmacol 1990, 38:567-572. | Article | PubMed

4. Plunkett W, Huang P, Searcy CE, Gandhi V: Gemcitabine: preclinical pharmacology and mechanisms of action. Semin Oncol 1996, 23:315. | Article I PubMed

5. Braakhuis BJ, Ruiz van Haperen VW, Welters MJ, Peters GJ: Scheduledependent therapeutic efficacy of the combination of gemcitabine and cisplatin in head and neck cancer xenografts. Eur J Cancer 1995, 31A:2335-2340. | Article | PubMed

6. Bergman AM, Ruiz van Haperen VW, Veerman G, Kuiper CM, Peters GJ: Synergistic interaction between cisplatin and gemcitabine in vitro. Clin Cancer Res 1996, 2:521-530. | Article | PubMed

7. Abratt RP, Sandler A, Crino L, Steward WP, Shepherd FA, Green MR, Nguyen B, Peters GJ: Combined cisplatin and gemcitabine for nonsmall cell lung cancer: influence of scheduling on toxicity and drug delivery. Semin Oncol 1998, 25:35-43. I Article I PubMed

8. Nishi K, Schnier JB, Bradbury EM: The accumulation of cyclin-dependent kinase inhibitor p27kip1 is a primary response to staurosporine and independent of G1 cell cycle arrest. Exp Cell Res 1998, 243:222-231. | Article | PubMed

9. Qiao L, Koutsos M, Tsai LL, Kozoni V, Guzman J, Shiff SJ, Rigas B: Staurosporine inhibits the proliferation, alters the cell cycle distribution and induces apoptosis in HT-29 human colon adenocarcinoma cells. Cancer Lett 1996, 107:83-89. | Article | PubMed

10. Abe K, Yoshida M, Usui T, Horinouchi S, Beppu T: Highly synchronous culture of fibroblasts from $\mathbf{G} 2$ block caused by staurosporine, a potent inhibitor of protein kinases. Exp Cell Res 1991, 192:122-127. | Article | PubMed

11. Gadbois DM, Hamaguchi JR, Swank RA, Bradbury EM: Staurosporine is a potent inhibitor of p34cdc2 and p34cdc2-like kinases. Biochem Biophys Res Commun 1992, 184:80-85. | Article I PubMed

12. Boix J, Llecha N, Yuste VJ, Comella JX: Characterization of the cell death process induced by staurosporine in human neuroblastoma cell lines. Neuropharmacology 1997, 36:811-821. | Article I PubMed

13. Akinaga S, Gomi K, Morimoto M, Tamaoki T, Okabe M: Antitumor activity of UCN-01, a selective inhibitor of protein kinase $\mathrm{C}$, in murine and human tumor models. Cancer Res 1991, 51:4888-4892. | Article I PubMed

14. Kawakami K, Futami H, Takahara J, Yamaguchi K: UCN-01, 7-hydroxylstaurosporine, inhibits kinase activity of cyclin-dependent kinases and reduces the phosphorylation of the retinoblastoma susceptibility gene product in $\mathrm{A549}$ human lung cancer cell line. Biochem Biophys Res Commun 1996, 219:778-783. I Article I PubMed

15. Patel V, Lahusen T, Leethanakul C, Igishi T, Kremer M, QuintanillaMartinez L, Ensley JF, Sausville EA, Gutkind JS, Senderowicz AM: Antitumor activity of UCN-01 in carcinomas of the head and neck is associated with altered expression of cyclin D3 and p27(KIP1). Clin Cancer Res 2002, 8:3549-3560. | Article | PubMed

16. Abe S, Kubota T, Otani Y, Furukawa T, Watanabe M, Kumai K, Akiyama T, Akinaga S, Kitajima M: UCN-01 (7-hydoxystaurosporine) inhibits in vivo growth of human cancer cells through selective perturbation of G1 phase checkpoint machinery. Jpn J Cancer Res 2001, 92:537-545. | Article | PubMed

17. Akiyama T, Yoshida T, Tsujita T, Shimizu M, Mizukami T, Okabe M, Akinaga S: G1 phase accumulation induced by UCN-01 is associated with dephosphorylation of $\mathbf{R b}$ and CDK2 proteins as well as induction of CDK inhibitor p21/Cip1/WAF1/Sdi1 in p53-mutated human epidermoid carcinoma A431 cells. Cancer Res 1997, 57:1495-1501. | Article I PubMed Text

18. Shao RG, Shimizu T, Pommier Y: 7-Hydroxystaurosporine (UCN-01) induces apoptosis in human colon carcinoma and leukemia cells independently of p53. Exp Cell Res 1997, 234:388-397. | Article | PubMed 
19. Byrd JC, Shinn C, Willis CR, Flinn IW, Lehman T, Sausville E, Lucas D, Grever MR: UCN-01 induces cytotoxicity toward human CLL cells through a p53-independent mechanism. Exp Hematol 2001, 29:703708. | Article | PubMed

20. Giovannetti E, Backus HH, Wouters D, Ferreira CG, van Houten VM, Brakenhoff RH, Poupon MF, Azzarello A, Pinedo HM, Peters GJ: Changes in the status of $\mathrm{p} 53$ affect drug sensitivity to thymidylate synthase (TS) inhibitors by altering TS levels. Br J Cancer 2007, 96:769-775. | Article | PubMed Abstract | PubMed Full Text

21. Keepers YP, Pizao PE, Peters GJ, van Ark-Otte J, Winograd B, Pinedo HM: Comparison of the sulforhodamine $B$ protein and tetrazolium (MTT) assays for in vitro chemosensitivity testing. Eur J Cancer 1991, 27:897-900. | PubMed

22. Chou TC, Talalay P: Quantitative analysis of dose-effect relationships: the combined effects of multiple drugs or enzyme inhibitors. Adv Enzyme Regul 1984, 22:27-55. | Article | PubMed

23. Sigmond J, Bergman AM, Leon LG, Loves WJ, Hoebe EK, Peters GJ: Staurosporine increases toxicity of gemcitabine in non-small cell lung cancer cells: role of protein kinase $\mathrm{C}$, deoxycytidine kinase and ribonucleotide reductase. Anticancer Drugs 2010, 21:591-599. Article I PubMed

24. Zhou XY, Wang X, Hu B, Guan J, lliakis G, Wang Y: An ATM-independent S-phase checkpoint response involves CHK1 pathway. Cancer Res 2002, 62:1598-1603. | Article | PubMed

25. Kohn EA, Ruth ND, Brown MK, Livingstone M, Eastman A: Abrogation of the $S$ phase DNA damage checkpoint results in $S$ phase progression or premature mitosis depending on the concentration of 7-hydroxystaurosporine and the kinetics of Cdc25C activation. J Biol Chem 2002, 277:26553-26564. | Article | PubMed

26. Monks A, Harris ED, Vaigro-Wolff A, Hose CD, Connelly JW, Sausville EA: UCN-01 enhances the in vitro toxicity of clinical agents in human tumor cell lines. Invest New Drugs 2000, 18:95-107. | Article | PubMed

27. Hubeek I, Peters GJ, Broekhuizen AJ, Sargent J, Gibson BE, Creutzig U, Kaspers GJ: Potentiation of in vitro ara-C cytotoxicity by ribonucleotide reductase inhibitors, cyclin-dependent kinase modulators and the DNA repair inhibitor aphidicolin in paediatric acute myeloid leukaemia. Br J Haematol 2005, 131:219-222. | Article | PubMed

28. Shao RG, Cao CX, Pommier Y: Abrogation of Chk1-mediated S/G2 checkpoint by UCN-01 enhances ara-C-induced cytotoxicity in human colon cancer cells. Acta Pharmacol Sin 2004, 25:756-762. | Pdf I PubMed

29. Sigmond J, Comijn EM, Kamphuis JA, Peters GJ: Combinations of 5-fluorouracil with UCN-01 or staurosporine. Nucleosides Nucleotides Nucleic Acids 2004, 23:1503-1506. | Article | PubMed

30. Shi Z, Azuma A, Sampath D, Li YX, Huang P, Plunkett W: S-Phase arrest by nucleoside analogues and abrogation of survival without cell cycle progression by 7-hydroxystaurosporine. Cancer Res 2001, 61:1065-1072. | Article | PubMed

31. Parsels LA, Morgan MA, Tanska DM, Parsels JD, Palmer BD, Booth RJ, Denny WA, Canman CE, Kraker AJ, Lawrence TS, Maybaum J: Gemcitabine sensitization by checkpoint kinase 1 inhibition correlates with inhibition of a Rad51 DNA damage response in pancreatic cancer cells. Mol Cancer Ther 2009, 8:45-54. | Article | PubMed Abstract I PubMed Full Text

32. Harvey S, Decker R, Dai Y, Schaefer G, Tang L, Kramer L, Dent P, Grant $S$ : Interactions between 2-fluoroadenine 9-beta-D-arabinofuranoside and the kinase inhibitor UCN-01 in human leukemia and lymphoma cells. Clin Cancer Res 2001, 7:320-330. | Article | PubMed

33. Sigmond J, Peters GJ: Pyrimidine and purine analogues, effects on cell cycle regulation and the role of cell cycle inhibitors to enhance their cytotoxicity. Nucleosides Nucleotides Nucleic Acids 2005, 24:1997-2022. | Article | PubMed

34. Montano R, Chung I, Garner KM, Parry D, Eastman A: Preclinical development of the novel Chk1 inhibitor SCH900776 in combination with DNA-damaging agents and antimetabolites. Mol Cancer Ther 2012, 11:427-438. | Article | PubMed

35. Kroep JR, Loves WJ, van der Wilt CL, Alvarez E, Talianidis I, Boven E,
Braakhuis BJ, van Groeningen CJ, Pinedo HM, Peters GJ: Pretreatment deoxycytidine kinase levels predict in vivo gemcitabine sensitivity. Mol Cancer Ther 2002, 1:371-376. | Article | PubMed

36. Csapo Z, Keszler G, Safrany G, Spasokoukotskaja T, Talianidis I, Staub $M$, Sasvari-Szekely M: Activation of deoxycytidine kinase by gammairradiation and inactivation by hyperosmotic shock in human lymphocytes. Biochem Pharmacol 2003, 65:2031-2039. | Article | PubMed

37. Smal C, Cardoen S, Bertrand L, Delacauw A, Ferrant A, Van den Berghe G, Van Den Neste E, Bontemps F: Activation of deoxycytidine kinase by protein kinase inhibitors and okadaic acid in leukemic cells. Biochem Pharmacol 2004, 68:95-103. | Article | PubMed

38. Csapo Z, Sasvari-Szekely M, Spasokoukotskaja T, Talianidis I, Eriksson $\mathrm{S}$, Staub M: Activation of deoxycytidine kinase by inhibition of DNA synthesis in human lymphocytes. Biochem Pharmacol 2001, 61:191197. | Article | PubMed

39. Smal C, Bertrand L, Van den Neste E, Cardoen S, Veiga-da-Cunha M, Marie S, Race V, Ferrant A, Van den Berghe G, Bontemps F: New evidences for a regulation of deoxycytidine kinase activity by reversible phosphorylation. Nucleosides Nucleotides Nucleic Acids 2004, 23:1363-1365. | Article | PubMed

\section{Citation:}

Sigmond J, Leon L, Kamphuis J, Bergman A and Peters G: Effect of staurosporine and ucn-01 on gemcitabine cytotoxicity in relation to cell cycle effects and p53 status. journal of Cancer Therapeutics and Research 2012, 1:29.

http://dx.doi.org/10.7243/2049-7962-1-29 